\title{
Ion Channels in Epithelial Dynamics and Morphogenesis
}

\author{
Ankit Roy Choudhury (D), Jörg Großhans (1) and Deqing Kong * (D) \\ Department of Biology, Philipps University, 35043 Marburg, Germany; \\ ankit.roychoudhury@biologie.uni-marburg.de (A.R.C.); grosshan@uni-marburg.de (J.G.) \\ * Correspondence: deqing.kong@biologie.uni-marburg.de
}

check for

updates

Citation: Roy Choudhury, A.; Großhans, J.; Kong, D. Ion Channels in Epithelial Dynamics and Morphogenesis. Cells 2021, 10, 2280. https://doi.org/10.3390/cells10092280

Academic Editor: Krzysztof Jagla

Received: 28 July 2021

Accepted: 30 August 2021

Published: 1 September 2021

Publisher's Note: MDPI stays neutral with regard to jurisdictional claims in published maps and institutional affiliations.

\begin{abstract}
Mechanosensitive ion channels mediate the neuronal sensation of mechanical signals such as sound, touch, and pain. Recent studies point to a function of these channel proteins in cell types and tissues in addition to the nervous system, such as epithelia, where they have been little studied, and their role has remained elusive. Dynamic epithelia are intrinsically exposed to mechanical forces. A response to pull and push is assumed to constitute an essential part of morphogenetic movements of epithelial tissues, for example. Mechano-gated channels may participate in sensing and responding to such forces. In this review, focusing on Drosophila, we highlight recent results that will guide further investigations concerned with the mechanistic role of these ion channels in epithelial cells.
\end{abstract}

Keywords: Drosophila; epithelial cells; morphogenesis; mechano-gated ion channels; calcium ion

\section{Introduction}

Epithelial cells constitute one of the four general tissue types. Epithelial tissue does not only cover the whole organism as such but also wraps all the visceral organs. Epithelial cells are polarised, i.e., the cortical proteins and organelles are differentially distributed. Tight and septate junctions segregate the apical side from the basal within a typical epithelial sheet, forming a diffusion barrier. In contrast, epithelial cells differ internally within the plane of a tissue sheet, establishing planar cell polarity [1]. Epithelial tissues are meant to undergo a series of morphodynamic and functional changes in the course of development.

Individual epithelial cells communicate chemically or mechanically to promote tissue morphogenesis, remodelling, and pattern formation [2]. Chemical coordination is widespread and long-lived but time-consuming. On the contrary, mechanical communication is almost instantaneous, although spatially limited, between neighbouring cells [3]. It is remarkable how thousands of epithelial cells work in unison to polarise their forcegenerating types of machinery and remodel their contacts during such tissue-scale changes. The adherens junctions and cytoskeleton mediate mechanical communication. At the centre of adherens junctions, E-cadherin-catenin complexes constitute the mechanical link between neighbours by the $\mathrm{Ca}^{2+}$-dependent homotypic trans-binding of two extracellular domains. $\alpha$-catenin links adherens junctions to the cytoskeleton [4]. Mechanical forces from the actin cytoskeleton prompt the conformational change in $\alpha$-catenin from its closed to open state, facilitating actin-binding protein vinculin to interact with $\alpha$-catenin. The link between E-cadherin clusters and the cytoskeleton is reinforced and strengthened in this manner (Figure 1a) [5,6]. Besides adherence junctions, integrin-rich focal adhesion sites at the basal domain of epithelial cells establish mechanical reciprocity between the viscoelasticity of the ECM and the traction force exerted by the cell [7]. Integrins are essential for epithelial polarisation around epidermal wounds in Drosophila, eventually leading to the closure [8].

Yet another category of mechanosensitive proteins, called mechano-gated ion channels (MGCs), had long been elusive for functioning in epithelial cell communication (Figure 1a). During the last two decades, several researchers gradually pointed out the existence and importance of these channels in the spectrum of model organisms, including Drosophila [9-11]. 
In Drosophila, such channels were initially identified in the sensory neurons, primarily involved in proprioception, nociception, hearing, locomotion, etc. [12,13]. These channels remain in "open" or "closed" conformational states. The switching between these states is regulated by mechanical force exerted by the plasma membrane or the cytoskeletal proteins [14]. Being in the open state, MGCs exhibit permeability to the ions, such as $\mathrm{Ca}^{2+}$, $\mathrm{K}^{+}, \mathrm{Na}^{+}$, and $\mathrm{Cl}^{-}$, which act as effector molecules to induce various signalling pathways. For example, $\mathrm{Ca}^{2+}$ has been shown to promote epithelial tight junction remodelling by activating RhoA in Xenopus embryonic epithelium (Figure 1b) [15].

(a)

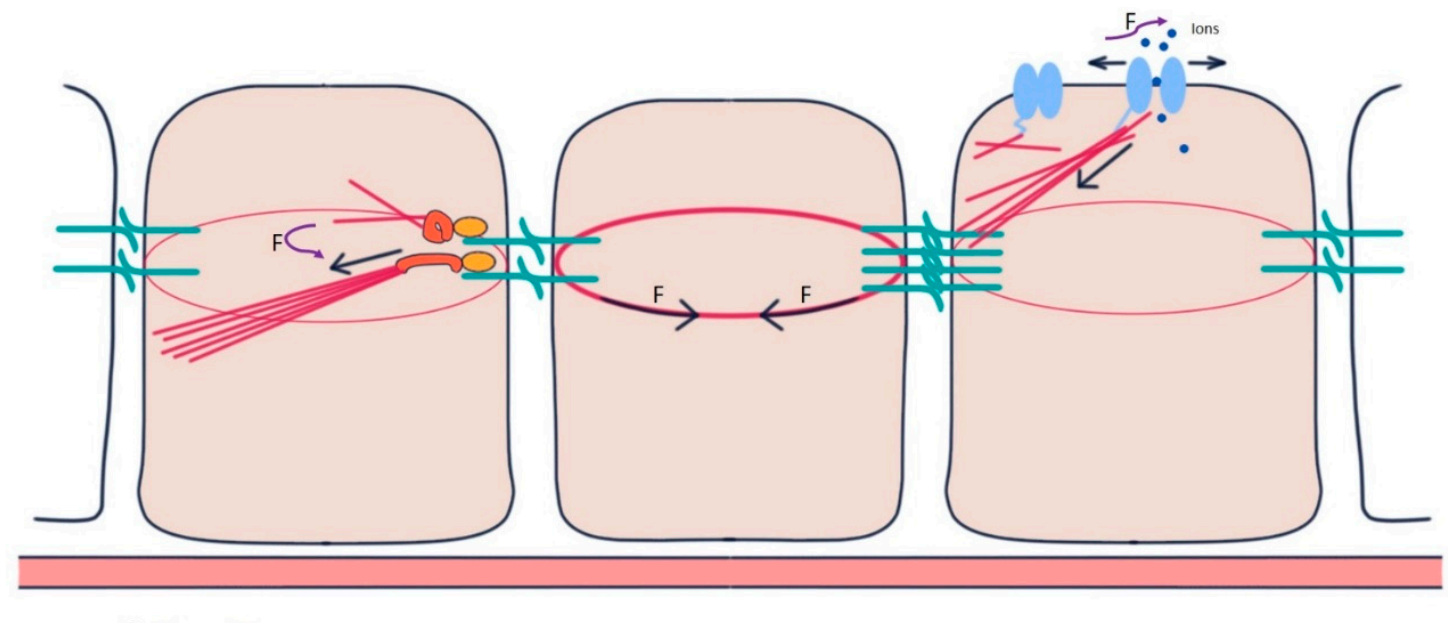

(b)
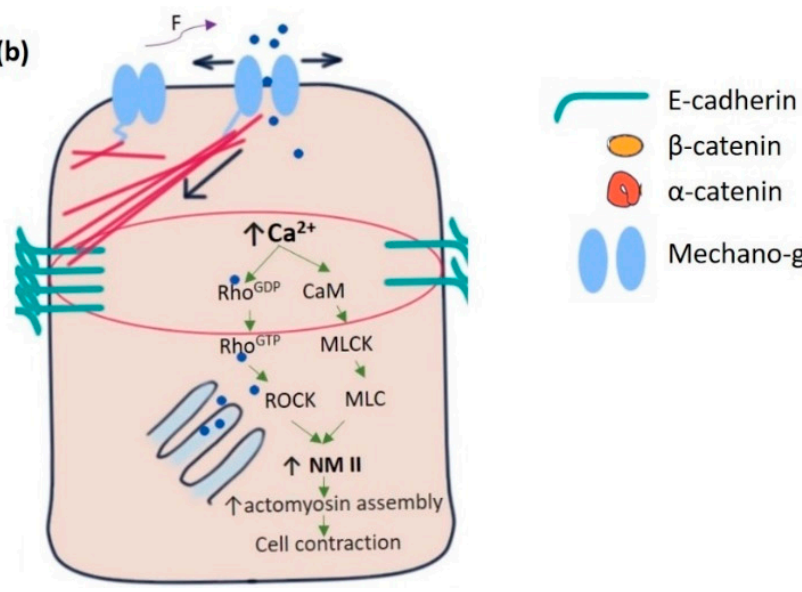

Mechano-gated ion channel

Figure 1. Mechanotransduction machinery in epithelial cells. (a) The E-cadherin-catenin complex is the key to adherens junction-mediated mechanotransduction. Pulling force $(\mathrm{F})$ due to the contractile actin ring of the cell at the centre promotes a force-induced conformational change in $\alpha$-catenin from closed to open conformation in the cell at the left. $\alpha$-catenin at its open conformation binds with actin-binding protein vinculin and acts as an actin nucleator. Mechano-gated channels (in the cell at right) can sense forces directly from the membrane or the cytoskeleton. In response, they change conformation from closed to open state and allow the ions to flow in and out of the cell. (b) Increased intracellular Ca ${ }^{2+}$ concentration in epithelial cells modulates the actomyosin assembly by activating non-muscle myosin II (NMII), the principal effector molecule. CaM, Calmodulin, MLCK, myosin light chain kinase, MLC, Myosin light chains, ROCK, Rho-associated kinase.

This review will focus on Drosophila and highlight some of the promising new developments that have paved the way to investigate further the mechanistic role of these ion channels in epithelial cells with greater detail.

\section{Epithelial Cells in Drosophila}

In Drosophila, the epithelial epidermis undergoes a series of spatially defined morphogenetic movements from gastrulation onwards, including tissue invagination, collective cell migration, convergent extension, dorsal closure, tube formation, head involution, etc. [16]. Coordination among the epithelial cells is necessary to ensure tissue integrity for the mor- 
phogenetic events to occur seamlessly [17]. Endodermal cell masses from both the ends of the Drosophila embryo collectively migrate along the visceral mesoderm and merge to form the continuous gut epithelium [18]. Yeast ingestion-induced stretching of mature gut epithelium causes yki (yorkie)-mediated proliferation, lacking which the tissue may undergo atrophy [19]. Coordinated asynchronous oscillations of the follicle cells in the Drosophila ovary are essential for egg-chamber elongation [20]. The E-cadherin-based mechanical connection between border and nurse cells is necessary for border cell migration in the egg chamber [21]. In Figure 2, we exemplify a few of the dynamic epithelial tissue types and morphological characteristics of the cells involved.

(a)

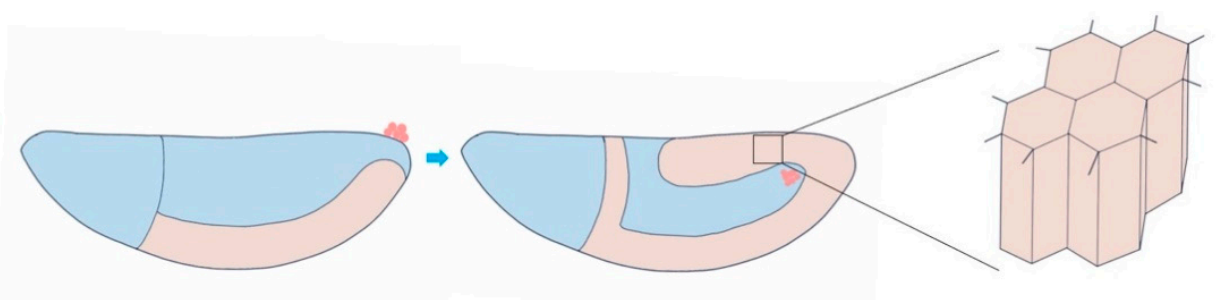

(b)
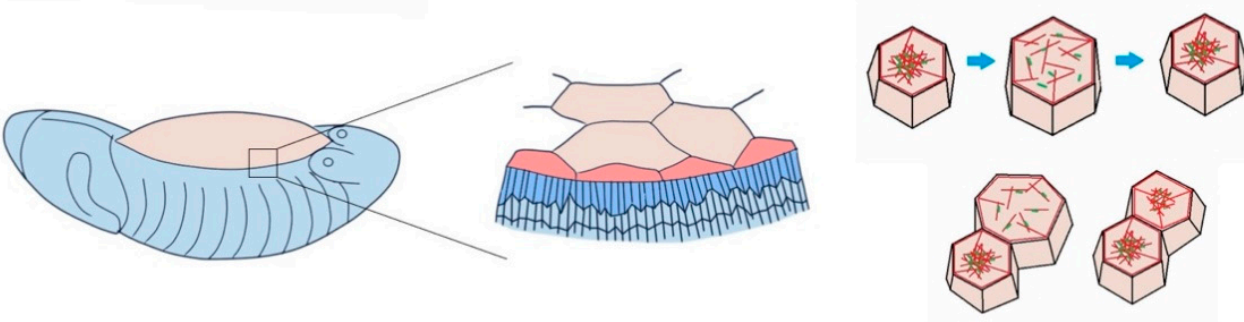

(c)
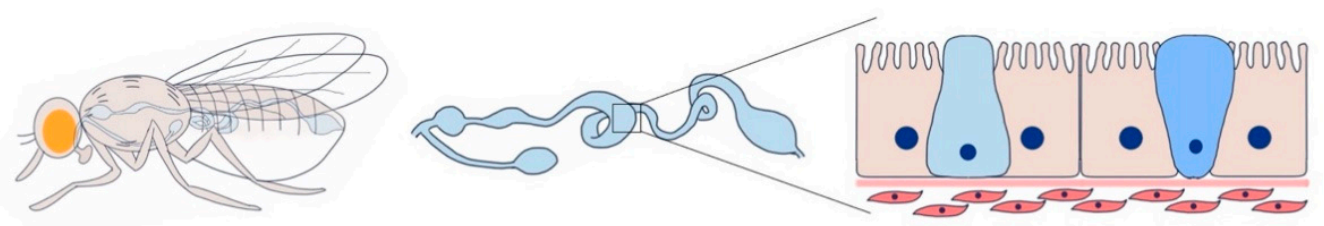

(d)
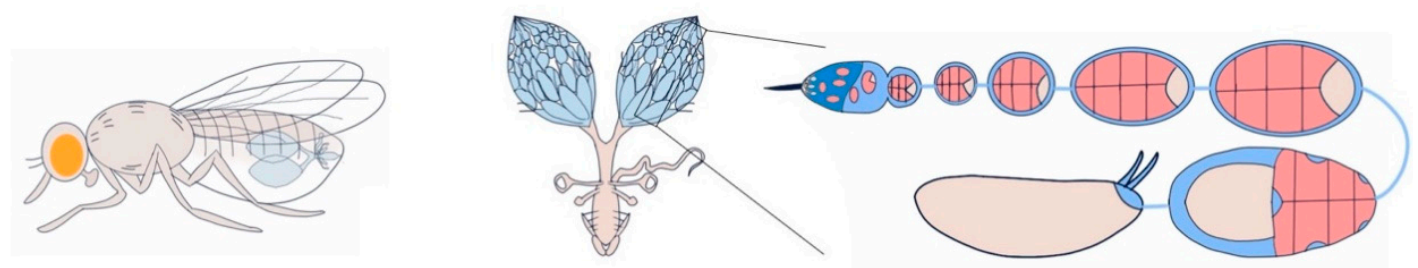

Figure 2. Dynamic epithelial tissues during morphogenesis and homeostasis in Drosophila. (a) Highly dynamic columnar epithelial cells of the germband during germband extension. The frequency of $\mathrm{Ca}^{2+}$ spikes increases during the first fast phase of germband extension, though the correlation with cell and junction dynamics are still unclear. (b) Periodically oscillating squamous epithelial cells of amnioserosa before dorsal closure. Neighbouring cells are either positively (contract and relax together) or negatively (when one contracts, the other relaxes and vice versa) coupled. Negative coupling maintains the tissue area and integrity, whereas positive coupling induces closure. $\mathrm{Ca}^{2+}$ influx is sufficient to induce cell contraction guided by actomyosin assembly. (c) Drosophila midgut comprises a diverse group of cuboidal epithelial cells: enterocyte with microvilli for absorption, intestinal stem cell (light blue) for regeneration and proliferation, and enteroendocrine cell (dark blue) for secretion. $\mathrm{Ca}^{2+}$ induces proliferation of the intestinal stem cells. Piezo-mediated Ca ${ }^{2+}$ is attributed to initiating the differentiation of the enteroendocrine cells. (d) The Drosophila ovary consists of a series of developing egg chambers. A dense monolayer of somatic epithelial cells called follicle cells surrounds a single oocyte and 15 supporting nurse cells in each egg chamber. Egg chamber elongation largely depends on the asynchronous oscillation of these cells, which $\mathrm{Ca}^{2+}$ regulates. 


\section{Calcium Ion in the Epithelium}

The importance of calcium signalling in epithelial morphogenesis has been found to be crucial in various model organisms. The convergent extension is defective under the inhibition of calcium signalling in Zebrafish and Xenopus. In contrast, the experimentally induced increase in calcium ion $\left(\mathrm{Ca}^{2+}\right)$ concentration triggers gastrulation in Echinoidea, neural fold formation in Ambystoma, and egg chamber elongation in Drosophila [22-26]. Two patterns of $\mathrm{Ca}^{2+}$ activity have been reported in Drosophila early embryos: (a) $\mathrm{Ca}^{2+}$ waves that are spontaneous, repetitive, and are often followed by a wave of tissue contraction, and (b) $\mathrm{Ca}^{2+}$ spikes that arise stochastically in a single cell or a group of few cells and are transient [27]. In the Drosophila wing disc, intracellular $\mathrm{Ca}^{2+}$ transients act as a signal integrator and decrease over time as the wing disc matures [28,29]. Increased intracellular $\mathrm{Ca}^{2+}$ corresponds to intestinal stem cell proliferation in Drosophila by regulating calcineurin and CRTC (CREB-regulated transcriptional co-activator) [30]. In processes like wound healing, $\mathrm{Ca}^{2+}$ waves help build rapid communication across many cells [31,32]. $\mathrm{Ca}^{2+}$ spikes are proven to have a close connection with Wnt signalling, the inhibition of which leads to decreased spike activity and eventually morphogenetic impairment in the developing embryo [33-35]. Such waves and spikes temporally coincide and thus hold the potential to regulate various morphogenetic events like dorsal closure, cuticle formation, and head involution $[27,35]$.

The reciprocity between cell contraction and adherens junction-mediated force transduction to the neighbouring cells contributes to emergent tissue behaviours like folds and furrows formation [36]. Intracellular $\mathrm{Ca}^{2+}$ has long been a principal regulator of contraction in many cell types, including muscle cells, stromal fibroblasts, and epithelial cells in culture [37-40]. Experiments in Drosophila embryos pointed out the importance of intracellular $\mathrm{Ca}^{2+}$ to induce contractility in amnioserosa cells during dorsal closure, neural tube closure, and neural plate folding [41-44]. Ventral furrow formation during gastrulation and contraction of amnioserosa cells during dorsal closure revealed the "ratchet" mechanism caused by a pulsatile cortical network of medioapical actomyosin [45]. The contractility in such non-muscle cells is driven by non-muscle myosin II (NM II), primarily regulated by Rho-ROCK signalling [46-48]. In the follicle cells of the Drosophila blade, intracellular $\mathrm{Ca}^{2+}$ seems to control the basal concentration of NM II. Chelating cytosolic $\mathrm{Ca}^{2+}$ by BAPTA reduces basal NMII. The effect can be reversed by adding ionomycin, driving $\mathrm{Ca}^{2+}$ influx [26]. Intracellular $\mathrm{Ca}^{2+}$ can also directly form a complex with tetravalent calmodulin protein, activating myosin light chain kinase (MLCK) that activates the regulatory light chain of NM II (Figure 1b) [49,50].

The amnioserosa is a monolayer of 150-200 autonomously oscillating squamous epithelial cells covering the dorsal opening of developing Drosophila embryos at stages 13-15 (Figure 2b) $[51,52]$. Inducing rapid $\mathrm{Ca}^{2+}$ bursts by uncaging intracellular $\mathrm{Ca}^{2+}$ can trigger amnioserosa cell contraction in single-cell resolution by activating NM II, wherein $\mathrm{Ca}^{2+}$ is reported to be linked at the position of ROCK (Rho-associated kinase) in the Rho-ROCK pathway [53]. Besides directly phosphorylating the myosin II regulatory light chain (RLC), ROCK also prevents the dephosphorylation of NM II by inhibiting protein phosphatase I (PP I), stabilising the activated NM II [54]. Constitutive activation of MLCK in the entire amnioserosa results in the overall rounding of the cells. Expression in individual cells triggers premature apical constriction [55]. In 3T3 fibroblast cells, ROCK is more centrally localised, whereas MLCK is localised more towards the periphery [50]. This localisation bias has to do with the spatially differential stability of the actomyosin structure within a cell. It could be investigated further to confirm such an argument in epithelial cells.

\section{Mechanosensitive Ion Channels in the Epithelium}

Not only are highly specialised sensory cells involved in hearing and proprioception, but potentially almost every eukaryotic cell can sense the force from its milieu via the conformational changes of membrane-bound proteins or protein complexes, so-called mechanosensors. These mechanosensors can detect and transduce the external mechanical 
signal into a cell. Junctional molecules, cytoskeletal proteins, G-protein coupled receptors, and mechanosensitive ion channels (MSCs) constitute a wide range of mechanosensors [56,57]. MSCs are evolutionarily ancient, pore-forming integral membrane proteins present in literally every living organism from archaea to bacteria to eukaryotes [58]. While in an open state, they allow ions such as $\mathrm{Ca}^{2+}, \mathrm{Na}^{+}, \mathrm{K}^{+}$, and $\mathrm{Cl}^{-}$to flow into and out of cells. The gating behaviour, i.e., the transition from closed to open conformation of MSCs, is regulated either by forces parallel to the plasma membrane (membrane tension model) or by forces applied by the associated cytoskeletal or extracellular matrix proteins (tether model) $[14,59]$. Channels are considered mechanically gated if a specific stimulus is immediately followed by the ion flux, at least faster than any other known second messenger and if knockdown of their expression leads to a loss of mechanosensory response [60]. In the following, we will discuss several mechano-gated ion channels, namely, Piezo, transmembrane Channel-like Protein (Tmc), No Mechanoreceptor Potential C (NompC), Transmembrane protein 16 (TMEM16), epithelial sodium channel (DEG/ENaC), and two pore domain $\mathrm{K}^{+}$channel (K2P), in Drosophila epithelial morphogenesis (Figure 3).
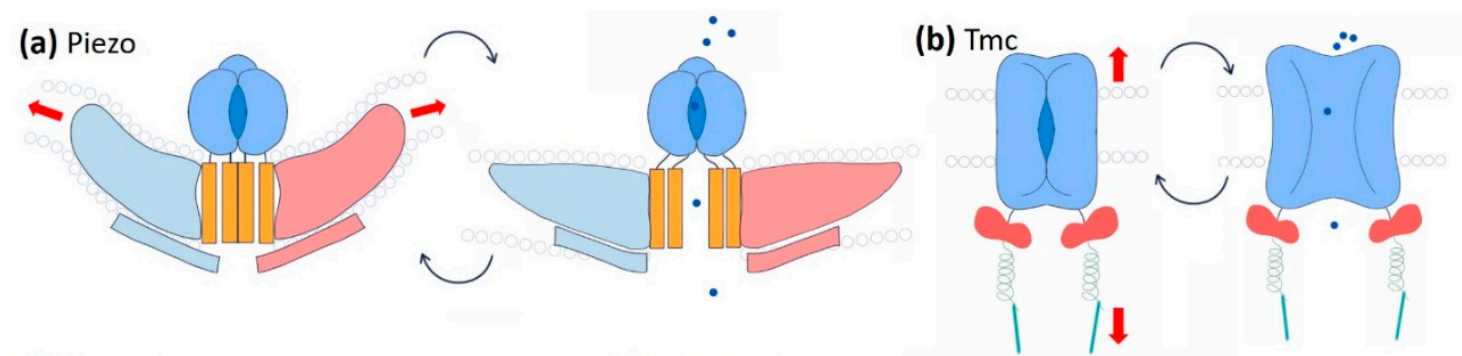

(c) NompC

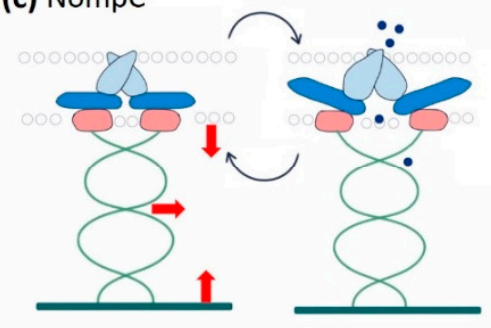

(e) $\mathrm{DEG} / \mathrm{ENaC}$

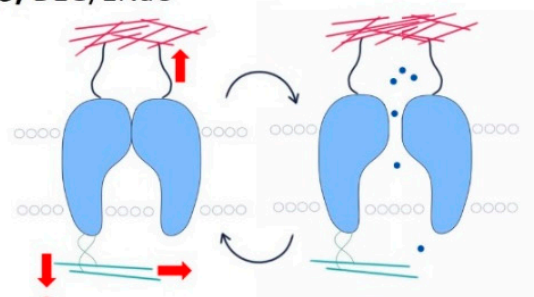

(d) TMEM16

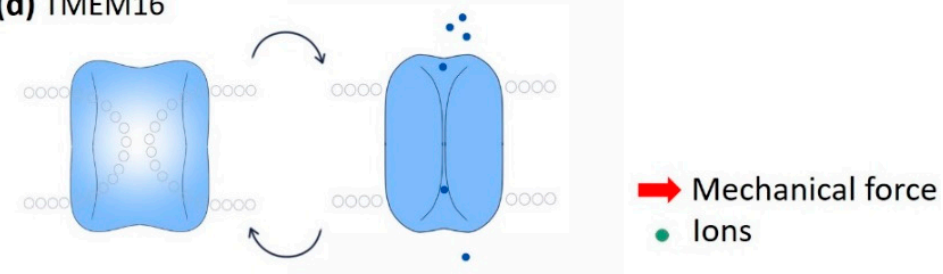

(f) $\mathrm{K} 2 \mathrm{P}$

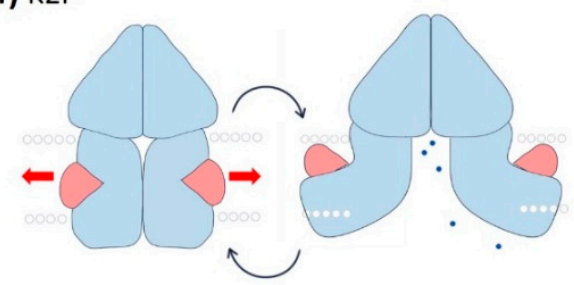

Figure 3. Schematic representation of mechano-gated channels and their gating mechanisms. (a) The Piezo channel is supposed to form a caveolae-like depression in the membrane. It is directly gated by membrane tension. Directional membrane tension flattens the channel to allow $\mathrm{Ca}^{2+}$ influx. (b) The transmembrane Channel-like Protein (Tmc channel) forms complexes with a group of other proteins that bring extracellular mechanical inputs. Intracellular Tmc is connected to the cytoskeleton by ankyrin and calcium-binding proteins. The channel is gated via the tension mediated by the tethering proteins from both extra and intracellular interfaces. (c) No Mechanoreceptor Potential C (NompC) has a substantially long (29 ankyrin repeats) cytoplasmic domain that interacts with the microtubules. The gating of NompC depends on the deflections of the ankyrin repeat helices mediated by the cytoskeleton components. (d) Transmembrane protein 16 (TMEM16) is a calcium-dependent chloride channel (CaCC). The dual function of TMEM16 as a lipid scramblase and as an ion channel makes it unique. These two functions are mutually exclusive and depend on the membrane tension-mediated conformational change of the protein. (e) The epithelial sodium channel (ENaC) interacts with both extracellular and intracellular proteins. Hydrostatic pressure, membrane stretch, and shear forces are the key mechanical cues that determine the gating of the channel pore. (f) The two pore domain $\mathrm{K}^{+}$channel $(\mathrm{K} 2 \mathrm{P})$, in its closed state, is blocked by the lipid. Membrane tension releases the lipid blockade and allows the hinge-like bending of the transmembrane domain and eventually ion flux. 


\subsection{Piezo Channel}

Since Piezo1/2 was discovered in 2010, many investigations have been conducted to reveal the structure and function of these novel groups of cation channels in eukaryotes [61]. Piezo proteins are approximately 2500 amino acids long and possess numerous transmembrane domains [62]. A cryo-EM study has revealed that Piezo consists of a central cap, three peripheral extracellular blade-like domains, and three long beams on the intracellular side (Figure 3a) [63]. Purified and membrane-incorporated Piezo1 allows cation influx across the membrane while subject to mechanical stress [64]. Piezo1 preferentially allows calcium influx in response to stimulation in whole-cell or outside-out patch-clamp recording [65]. GsMTx4, a peptide isolated from the tarantula spider and a known modifier of MSC gating, blocks Piezo1 activity [66]. A small molecule called Yoda1, on the contrary, can trigger Piezo1 and Piezo1-mediated calcium influx even in the absence of a mechanical stimulus [67]. Similar to Piezo1, Piezo2 also acts as a $\mathrm{Ca}^{2+}$-sensitive mechano-gated channel. Piezo2-mediated $\mathrm{Ca}^{2+}$-influx is reported to activate RhoA, which controls the assembly and orientation of stress fibres and focal adhesions [68].

Recent studies revealed the involvement of the Piezo channel in epithelial cell homeostasis using MDCK cells in culture. Piezo1 detects and transduces epithelial cell stretch at low-cell-density areas, resulting in cell division [69]. Genetic knockdown of Piezo1 hinders homeostatic cell extrusion in developing zebrafish epidermis, leading to the formation of epithelial cell clusters [70]. Piezo channels are expressed across the body in many different types of epithelial cells, subject to compressive and shear stresses, for example, vascular endothelial cells, mammary epithelial cells, urinary bladder cells, pancreatic acinar cells, and so on [71]. Piezo1 knockout causes embryonic lethality of E14.5 mice due to impaired vasculogenesis [72]. Piezo2 has recently been discovered in the human enteroendocrine cell (EEC) population [73].

The Drosophila genome contains two Piezo genes: Piezo, an ortholog, and piezo-like (Pzl), a homolog of Piezo gene families. Piezo knockout flies are viable and fertile, and it seems not to induce major developmental defects. Piezo knockout larvae show severely reduced behavioural responses to noxious mechanical stimuli [12]. Pzl is functional in proprioceptive chordotonal neurons of Drosophila larvae. Loss of Pzl severely affects the locomotion and body gesture control in the larvae and can be rescued by the expression of human or mouse Piezo1 [74]. Drosophila midgut, analogous to the stomach and small intestine in vertebrates, has a distinct population of intestinal stem cells. These cells commit to becoming secretory EECs under the influence of low Notch signalling, constituting $1 \%$ gut epithelial cells. Distension of the gut by mechanical forces triggers the differentiation of Piezo ${ }^{+}$EEC precursors into Piezo ${ }^{+}$EEC. He et al. [75] proposed that Piezo-mediated $\mathrm{Ca}^{2+}$ influx and Notch inhibition were sufficient to drive the EEC differentiation through a series of experiments. On the other hand, ERK signalling drives EEC cell proliferation but not differentiation $[75,76]$. These findings raise open questions like whether these pathways are mechanically interlinked and Piezo's possible implication in human gastrointestinal pathologies.

\subsection{Transmembrane Channel-like Protein (Tmc)}

The TMC family comprises integral membrane proteins of a $\sim 115$ amino acid-long TMC domain that starts with a highly conserved "CWET" signature sequence (Figure 3b) [77]. Vertebrates have eight TMC proteins encoded by TMC1-8 genes [78,79]. TMC4 is expressed in the kidney, small intestine, and colon epithelia. It is proposed to form a Ca${ }^{2+}$-dependent $\mathrm{Cl}^{-}$ channel [80]. TMC6 and TMC8 are associated with zinc transporters in keratinocytes [81]. Mechanosensory functions of TMC proteins are not conclusive except for TMC1 and TMC2, which are found to form the core of a multimeric mechanosensitive complex in auditory hair cells and lateral line organs of fish $[82,83]$. A sound wave creates deflections of the "hair bundle," a cluster of actin-rich stereocilia located at the apical surface of the hair cells. Extracellular protein filaments called "tip links" transmit mechanical distortions to the MSCs at the stereocilia tips [84]. Tip links interact with protocadherin-15 (PCDH15) 
homodimers, transmembrane, and cytoplasmic domains, further interacting with the TMC proteins $[85,86]$. In C. elegans, ankyrin is found to tether TMC channels intracellularly like a spring via Calcium and Integrin Binding protein, CALM-1 [87].

Both TMC1 and TMC2 are highly selective to $\mathrm{Ca}^{2+}$; however, TMC2 has $\sim 3$-fold higher selectivity than TMC1 [88]. In mice, TMC2 is expressed from birth to postnatal day 10 and then declines to zero, followed by expression of TMC1 that continues throughout life [89]. The upsurge of TMC1 localisation at the tips of hair cell stereocilia parallels with the onset of auditory function $[88,90]$. TMC1 and TMC2 seem to have mutually distinct physiological functions, as the expression of TMC2 cannot compensate for the loss of expression of TMC1 in auditory hair cells. Zebrafish neuromast cells along the lateral line organ can be classified into three groups based on their differential reliance on the TMC $2 \mathrm{~b}$ channel for mechanotransduction [83].

In Drosophila, the only Tmc gene translates to the protein. The sequence is highly conserved with $T m c$ family members across different organisms. Tmc is expressed in Class I da, Class II da, and bd sensory neurons. Tmc mutant larvae have defects in locomotion, and adults show difficulty in food texture sensation [91]. The roles of Tmc in epithelial morphogenesis have not been studied thoroughly yet. Our work indicates an essential function of $T m c$ in homogenous tension distribution across the oscillating amnioserosa cells and maintaining the synchronisation of neighbouring cells [92]. Moreover, Tmc null embryos exhibit a significant reduction in $\mathrm{Ca}^{2+}$ influx in response to wounding or tissue damage. It is worth investigating the molecular mechanism and the direct interacting partners of Tmc in the future.

\subsection{No Mechanoreceptor Potential C (nompC)}

nompC is the only member of the TRPN family that comes under a large superfamily of characterised or putative MSC proteins, known as transient receptor potential (TRP) channels. The TRP superfamily consists of more than 30 cation channels, most of which are permeable to either $\mathrm{Ca}^{2+}$ or $\mathrm{Mg}^{2+}$ [93]. The gene nompC was first identified in Drosophila in a screen for mechanoreceptive mutants with defects in mechanosensory physiology. Lossof-function point mutations of nompC abolish the mechanosensory transduction current. Various nonsense and missense point mutations of nompC cause a series of defects in Drosophila, such as hearing impairment, locomotion, gentle touch sensation, adaptive response to mechanical stimuli, and food texture sensation [13]. The structure of NompC was described in 2017 by single-particle cryo-electron microscopy. NompC protein contains a short transmembrane neck domain and a distinctive 29 ankyrin repeats-long helical cytoplasmic domain (Figure 3c). NompC ankyrin repeats interact with microtubules and is implicated as a rope to convey force from the cytoskeleton to the channel, thus controlling the gating $[94,95]$. Most TRP channels are reported to be permeable for monovalent cations like $\mathrm{Na}^{+}$and $\mathrm{K}^{+}$and divalent cations like $\mathrm{Ca}^{2+}[96-98]$. $\mathrm{Ca}^{2+}$ influx is proposed to change the state of motor proteins that, in turn, adjust cellular tension [97].

A recent finding demonstrates that nompC point mutations are attributed to defective dorsal closure phenotypes in the Drosophila, such as irregular purse string and increased embryonic lethality [99]. Furthermore, induced expression of NompC constructs with truncated ankyrin repeats in amnioserosa leads to defects in dorsal closure, like failure to organise an actomyosin purse string, loss of leading-edge cell elongation, and so on [99]. Taking these results into account, it is worth investigating the physiological relevance of nотрC in amnioserosa and the underlying mechanism of NompC mechanotransduction that leads to the rapid tissue-scale transmission of multidirectional forces.

\subsection{Transmembrane Protein 16 (TMEM16)}

Though in the early 1980s, $\mathrm{Ca}^{2+}$-activated $\mathrm{Cl}^{-}$channel (CaCC) activity was observed in frog oocytes $[100,101]$, three groups independently developed their molecular identity in 2008. The gene encoding TMEM16A is responsible for the $\mathrm{Cl}^{-}$currents in response to increased intracellular $\mathrm{Ca}^{2+}$ concentration [102-104]. The TMEM family includes CaCCs 
like TMEM16A and TMEM16B. Most family members are $\mathrm{Ca}^{2+}$-activated scramblases, facilitating bidirectional diffusion of lipids between membrane leaflets [105]. Cryo-EM revealed that TMEM16A is a dimeric channel. Each subunit includes 10 transmembrane segments (Figure 3d) [106]. In silico analysis demonstrates an evolutionary connection of TMEM with a $\mathrm{Ca}^{2+}$-permeable stress gated cation channel (CSC), Tmc, etc. [107]. In human and mouse bile duct epithelial cells or cholangiocytes, shear stress is shown to activate TMEM16A-mediated $\mathrm{Cl}^{-}$transport, a process dependent on extracellular ATP and intracellular $\mathrm{Ca}^{2+}$. The mechanical stimuli do not directly regulate the channel's gating; rather, it depends on the rate-driven delivery of ATP to the membrane (shear rate) [108].

In Drosophila, TMEM16A or subdued is found in non-excitable epithelial cells and implicated in host defence [109-111]. An absence of TMEM16 is marked by dysmorphic epithelial organisation in the trachea, oesophagus, and kidney of mouse embryos [112]. TMEM16A is essential to maintain a critical level of cytoplasmic $\mathrm{Cl}^{-}$. Cytoplasmic $\mathrm{Cl}^{-}$ is necessary to regulate microdomain partitioning of $\mathrm{PI}(4,5) \mathrm{P}_{2}$, endocytic trafficking, and recycling endosome, ensuring membrane supply during ciliogenesis and junctional remodelling [112]. TMEM16A seems to have a bunch of activating agents working in parallel. It also appears to induce various signalling pathways upon activation. Hence, it is worth investigating the molecular association and the procedure of mechanical induction of TMEM16A more thoroughly.

\subsection{DEG/ENaC Channels}

Monovalent cations like sodium ions $\left(\mathrm{Na}^{+}\right)$are implicated in epithelial homeostasis and morphogenesis $[113,114]$. Recent studies have found multiple known sodium channels to be mechanically gated. $\mathrm{Na}_{\mathrm{v}} 1.5$, a voltage-sensitive sodium channel in the human heart and gut, is activated by membrane stretching. Mutations of this channel disrupt the mechanical sensitivity of gut epithelial cells, resulting in abdominal pain syndrome and irritable bowel syndrome [115]. Epithelial sodium channel $(\mathrm{ENaC})$ mediates passive sodium transport at the apical domain of many different epithelial cell types: kidney, lungs, skin, colon, and reproductive tract [116-120]. $\mathrm{ENaC}$ can be activated by shear force across organisms, especially in vascular endothelium, to maintain its tonicity [121]. Shear forces can be transduced by the N-glycosylated extracellular domain of $\mathrm{ENaC}$ tethering with extracellular matrix (ECM) [122]. ENaC directly interacts with spectrin, ankyrin, actin cytoskeleton, and actin-associated proteins [123-125]. Cellular responses to hydrostatic pressure differences and membrane stretch depend on such interactions [126]. Degenerin (Deg), C. elegans-specific ENaC, gained function mutations resulting in degenerations like swelling, vacuolation, and apoptosis [127]. Studying mechanoreceptor currents reveals activation of DEG channels in response to gentle and nociceptive mechanical stimuli [128].

Ripped pocket (Rpk) and Pickpocket (Ppk) were identified as two novel ENaC proteins in 1998 in Drosophila. rpk transcripts are abundant in early-stage embryos and adult ovaries, whereas ppk is only expressed in sensory neurons in late-stage embryos [129]. It points to the potential functions of $r p k$ during early embryonic development. Rpk localises in patches at the apical surface but not at the junctions of amnioserosa cells. Knockdown of $r p k$ in amnioserosa causes elongation failure of the lateral epidermis. $r p k$ mutant embryos show impaired epitheliogenesis, including defective germband extension, dorsal closure, head involution, and consequent lethality [41]. $r p k$ has recently been implicated in depolarising the membrane potential of anterior epithelial cells during imaginal disc development. Rpk expression in these cells depends on Hedgehog $(\mathrm{Hh})$ signalling. Suppression of $r p k$ leads to a reduction in depolarisation of anterior cells and a disruption in compartmentalisation between anterior and posterior cell populations [130].

\subsection{K2P Channels}

The K2P (two pore domain $\mathrm{K}^{+}$channel) family of channels are potassium $\left(\mathrm{K}^{+}\right)$channels made of a dimeric assembly of two subunits, each containing four transmembrane domains [131]. The channel was first identified in yeast [132]. Later on, 15 channels of the 
K2P family were discovered in mammals by sequence homology screening of the pore domain region [133]. Out of these 15 channels, three channels appear to be mechanically gated, namely, TREK-1 (TWIK-related $\mathrm{K}^{+}$channel 1), TREK-2, and TRAAK (TWIK-related arachidonic acid-stimulated $\mathrm{K}^{+}$channel). $\mathrm{K}^{+}$currents through these channels can be mechanically induced by membrane stretch in both in vitro and in vivo systems [134-136]. The Xenopus oocyte expressing TREK-1 channel shows induced channel activity upon mechanical stress like membrane stretch, osmotic swelling, and shear stress [137]. TREK-1 also induces actin cytoskeleton remodelling and colocalises with ezrin in filopodia-like structures [138]. Studies in the human alveolar epithelial cell line reveal that TREK-1 regulates cell deformability by cytoskeletal remodelling and cell detachment following mechanical stretch [139]. However, whether the cytoskeletal interaction is responsible for channel gating remains unclear.

TREK-1 is essential for the proliferation of the human endometrial epithelial cell line [140]. Deficiency of TREK-1 ortholog sandman in Drosophila causes cardiac fibrosis and diastolic dysfunction [141]. Decreased expression of Drosophila TREK-1 homolog Ork1 (Open rectifier potassium channel 1) has been found to modulate learning and sleep behaviour [142]. Cardiac-specific inactivation of Ork-1 causes increased heart rhythm [143]. The gating of K2P channels is regulated by the transmembrane domain (TM2.6), more specifically by a single amino acid (aspartate) residue in this domain both in the vertebrates and invertebrates like Drosophila [144,145]. The role of K2P channels is still not clear in epithelial cells in Drosophila. Promising studies from other model organisms and direct membrane-stress-induced mechano-gating like the Piezo channel held K2P channels worth investigating in Drosophila, especially in the context of epithelial morphogenesis where mechanical forces are very obvious and dynamic.

\section{Concluding Remarks}

Genome-wide studies have revealed the expression of mechano-gated and mechanosensitive ion channels outside of their typical cell types within the nervous system and neurosensory organs. Despite their presence, a physiological function of these channels has remained elusive in epithelia. The new-generation microscopy techniques and highthroughput quantitative image analysis have improved the tractability of tissue-wise cellular motions $[146,147]$. Hence, the changes in epithelial morphodynamics and the underlying biomechanical perturbations inflicted by the mutants of the mechano-gated channels can be studied in depth.

TRP channels like Trp1 are reported to severely affect the dorsal closure in Drosophila [41]. Although Trp1 is not yet shown to be mechanically gated, it can disrupt the force orchestration in and around amnioserosa tissue. Both mouse TRPM7 and its ortholog Trpm in Drosophila are shown to be responsible for $\mathrm{Ca}^{2+}$ influx during egg activation [148]. Knockdown of Trpm results in decreased intracellular calcium and impaired actomyosin cable formation in post-wounding Drosophila pupal notum epithelium [149]. TRPM7 is activated by mechanical triggers, but whether TrpM in Drosophila responds the same way in response to mechanical cues during ovulation remains unclear [148]. Two more Drosophila proteins, Brivido-1 (Brv1) and Tmem63, reportedly form mechano-gated ion channels. However, their roles in mechanotransduction are not clear. Brv1 coexpresses NompC in larval class III da neurons, where it seems to facilitate mechanoactive NompC currents in gentle touch sensation [150]. Tmem63 needs a relatively strong mechanical stimulus to get activated [151]. The expression and mechanosensory activities of these ion channels in the context of epithelial homeostasis and morphogenesis need to be addressed.

By combining the ions, cytoskeleton, and junctional proteins, mechanosensitive ion channels became a fascinating group of ion channels in the epithelium. For example, NompC was revealed to link to microtubules for channel opening, Piezo1 shows an essential function for Rho signalling, and the adherence junction is a defect in the TMEM16 mutant. These phenomena are awe-inspiring. It is worth investigating in the future whether (1) mechanosensitive ion channels interact with junctional proteins physically, 
(2) mechanosensitive ion channels coordinate with junctional proteins during mechanotransduction, and (3) mechanosensitive ion channels open via the mechanical forces from junction proteins.

Author Contributions: A.R.C. wrote the manuscript and drew the figures. J.G. and D.K. revised the manuscript. J.G. and D.K. conceived and edited the manuscript. All authors have read and agreed to the published version of the manuscript.

Funding: This research was funded by Deutsche Forschungsgemeinschaft (GR1945/10-1, GR1945/10-2). A.R.C. was supported by the Deutscher Akademischer Austauschdienst (DAAD).

Conflicts of Interest: The authors declare no conflict of interest.

\section{References}

1. Campanale, J.P.; Sun, T.Y.; Montell, D.J. Development and dynamics of cell polarity at a glance. J. Cell Sci. 2017, 130, 1201-1207. [CrossRef] [PubMed]

2. Salm, M.; Pismen, L.M. Chemical and mechanical signaling in epithelial spreading. Phys. Biol. 2012, 9, 026009. [CrossRef]

3. Janmey, P.A.; Miller, R.T. Mechanisms of mechanical signaling in development and disease. J. Cell Sci. 2011, 124, 9-18. [CrossRef] [PubMed]

4. $\quad$ Oda, H.; Uemura, T.; Harada, Y.; Iwai, Y.; Takeichi, M. A Drosophila Homolog of Cadherin Associated with Armadillo and Essential for Embryonic Cell-Cell Adhesion. Dev. Biol. 1994, 165, 716-726. [CrossRef]

5. Ishiyama, N.; Sarpal, R.; Wood, M.N.; Barrick, S.K.; Nishikawa, T.; Hayashi, H.; Kobb, A.B.; Flozak, A.S.; Yemelyanov, A.; Fernandez-Gonzalez, R.; et al. Force-dependent allostery of the $\alpha$-catenin actin-binding domain controls adherens junction dynamics and functions. Nat. Commun. 2018, 9, 5121. [CrossRef]

6. Kong, D.; Großhans, J. Planar Cell Polarity and E-Cadherin in Tissue-Scale Shape Changes in Drosophila Embryos. Front. Cell Dev. Biol. 2020, 8, 1710. [CrossRef]

7. Sun, Z.; Guo, S.S.; Fässler, R. Integrin-mediated mechanotransduction. J. Cell Biol. 2016, 215, 445-456. [CrossRef] [PubMed]

8. Park, S.-H.; Lee, C.; Lee, J.-H.; Park, J.Y.; Roshandell, M.; Brennan, C.A.; Choe, K.-M. Requirement for and polarized localization of integrin proteins during Drosophila wound closure. MBoC 2018, 29, 2137-2147. [CrossRef]

9. Maksaev, G.; Haswell, E.S. Expression and characterization of the bacterial mechanosensitive channel MscS in Xenopus laevis oocytes. J. Gen. Physiol. 2011, 138, 641-649. [CrossRef]

10. Bazopoulou, D.; Tavernarakis, N. Chapter 3-Mechanosensitive Ion Channels in Caenorhabditis elegans. In Current Topics in Membranes; Hamill, O.P., Ed.; Mechanosensitive Ion Channels, Part B; Academic Press: Waltham, MA, USA, 2007; Volume 59, pp. $49-79$.

11. Hehlert, P.; Zhang, W.; Göpfert, M.C. Drosophila Mechanosensory Transduction. Trends Neurosci. 2021, 44, 323-335. [CrossRef]

12. Kim, S.E.; Coste, B.; Chadha, A.; Cook, B.; Patapoutian, A. The role of Drosophila Piezo in mechanical nociception. Nature 2012, 483, 209-212. [CrossRef]

13. Walker, R.G.; Willingham, A.T.; Zuker, C.S. A Drosophila Mechanosensory Transduction Channel. Science 2000, 287, 2229-2234. [CrossRef] [PubMed]

14. Ranade, S.S.; Syeda, R.; Patapoutian, A. Mechanically Activated Ion Channels. Neuron 2015, 87, 1162-1179. [CrossRef]

15. Varadarajan, S.; Stephenson, R.E.; Misterovich, E.R.; Wu, J.L.; Erofeev, I.S.; Goryachev, A.B.; Miller, A.L. Mechanosensitive calcium signaling in response to cell shape changes promotes epithelial tight junction remodeling by activating RhoA. bioRxiv 2021 [CrossRef]

16. Lye, C.M.; Sanson, B. Chapter Five-Tension and Epithelial Morphogenesis in Drosophila Early Embryos. In Current Topics in Developmental Biology; Labouesse, M., Ed.; Forces and Tension in Development; Academic Press: Waltham, MA, USA, 2011; Volume 95, pp. 145-187.

17. Köppen, M.; Fernández, B.G.; Carvalho, L.; Jacinto, A.; Heisenberg, C.-P. Coordinated cell-shape changes control epithelial movement in zebrafish and Drosophila. Development 2006, 133, 2671-2681. [CrossRef]

18. Reuter, R.; Grunewald, B.; Leptin, M. A role for the mesoderm in endodermal migration and morphogenesis in Drosophila. Development 1993, 119, 1135-1145. [CrossRef]

19. Li, Q.; Nirala, N.K.; Nie, Y.; Chen, H.-J.; Ostroff, G.; Mao, J.; Wang, Q.; Xu, L.; Ip, Y.T. Ingestion of Food Particles Regulates the Mechanosensing Misshapen-Yorkie Pathway in Drosophila Intestinal Growth. Dev. Cell 2018, 45, 433-449.e6. [CrossRef] [PubMed]

20. Koride, S.; He, L.; Xiong, L.-P.; Lan, G.; Montell, D.J.; Sun, S.X. Mechanochemical regulation of oscillatory follicle cell dynamics in the developing Drosophila egg chamber. MBoC 2014, 25, 3709-3716. [CrossRef]

21. Cai, D.; Chen, S.-C.; Prasad, M.; He, L.; Wang, X.; Choesmel-Cadamuro, V.; Sawyer, J.K.; Danuser, G.; Montell, D.J. Mechanical feedback through E-cadherin promotes direction sensing during collective cell migration. Cell 2014, 157, 1146-1159. [CrossRef] [PubMed]

22. Lam, P.Y.; Webb, S.E.; Leclerc, C.; Moreau, M.; Miller, A.L. Inhibition of stored Ca2+ release disrupts convergence-related cell movements in the lateral intermediate mesoderm resulting in abnormal positioning and morphology of the pronephric anlagen in intact zebrafish embryos. Dev. Growth Differ. 2009, 51, 429-442. [CrossRef] 
23. Wallingford, J.B.; Ewald, A.J.; Harland, R.M.; Fraser, S.E. Calcium signaling during convergent extension in Xenopus. Curr. Biol. 2001, 11, 652-661. [CrossRef]

24. Lane, M.C.; Koehl, M.A.; Wilt, F.; Keller, R. A role for regulated secretion of apical extracellular matrix during epithelial invagination in the sea urchin. Development 1993, 117, 1049-1060. [CrossRef] [PubMed]

25. Moran, D.; Rice, R.W. Action of papaverine and ionophore A23187 on neurulation. Nature 1976, 261, 497-499. [CrossRef]

26. He, L.; Wang, X.; Tang, H.L.; Montell, D.J. Tissue elongation requires oscillating contractions of a basal actomyosin network. Nat. Cell Biol. 2010, 12, 1133-1142. [CrossRef]

27. Markova, O.; Senatore, S.; Lenne, P.-F. Spatiotemporal dynamics of calcium transients during embryogenesis of Drosophila melanogaster. bioRxiv 2019. [CrossRef]

28. Brodskiy, P.A.; Wu, Q.; Soundarrajan, D.K.; Huizar, F.J.; Chen, J.; Liang, P.; Narciso, C.; Levis, M.K.; Arredondo-Walsh, N.; Chen, D.Z.; et al. Decoding Calcium Signaling Dynamics during Drosophila Wing Disc Development. Biophys. J. 2019, 116, 725-740. [CrossRef] [PubMed]

29. Balaji, R.; Bielmeier, C.; Harz, H.; Bates, J.; Stadler, C.; Hildebrand, A.; Classen, A.-K. Calcium spikes, waves and oscillations in a large, patterned epithelial tissue. Sci. Rep. 2017, 7, 42786. [CrossRef] [PubMed]

30. Deng, H.; Gerencser, A.A.; Jasper, H. Signal integration by Ca2+ regulates intestinal stem cell activity. Nature 2015, 528, $212-217$. [CrossRef]

31. Jaffe, L.F. Fast calcium waves. Cell Calcium 2010, 48, 102-113. [CrossRef] [PubMed]

32. Leybaert, L.; Sanderson, M.J. Intercellular Ca ${ }^{2+}$ Waves: Mechanisms and Function. Physiol. Rev. 2012, 92, 1359-1392. [CrossRef]

33. Slusarski, D.C.; Corces, V.G.; Moon, R.T. Interaction of Wnt and a Frizzled homologue triggers G-protein-linked phosphatidylinositol signalling. Nature 1997, 390, 410-413. [CrossRef]

34. Sheldahl, L.C.; Slusarski, D.C.; Pandur, P.; Miller, J.R.; Kühl, M.; Moon, R.T. Dishevelled activates Ca2+ flux, PKC, and CamKII in vertebrate embryos. J. Cell Biol. 2003, 161, 769-777. [CrossRef] [PubMed]

35. Markova, O.; Lenne, P.-F. Calcium signaling in developing embryos: Focus on the regulation of cell shape changes and collective movements. Semin. Cell Dev. Biol. 2012, 23, 298-307. [CrossRef]

36. Liang, X.; Gomez, G.A.; Yap, A.S. Current perspectives on cadherin-cytoskeleton interactions and dynamics. CHC 2015, 7, 11-24. [CrossRef]

37. Kuo, I.Y.; Ehrlich, B.E. Signaling in Muscle Contraction. Cold Spring Harb. Perspect. Biol. 2015, 7, a006023. [CrossRef]

38. Nobe, K.; Nobe, H.; Obara, K.; Paul, R.J. Preferential role of intracellular Ca2+ stores in regulation of isometric force in NIH 3T3 fibroblast fibres. J. Physiol. 2000, 529, 669-679. [CrossRef] [PubMed]

39. Lembong, J.; Sabass, B.; Stone, H.A. Calcium oscillations in wounded fibroblast monolayers are spatially regulated through substrate mechanics. Phys. Biol. 2017, 14, 045006. [CrossRef] [PubMed]

40. Lee, H.C. Calcium in epithelial cell contraction. J. Cell Biol. 1980, 85, 325-336. [CrossRef]

41. Hunter, G.L.; Crawford, J.M.; Genkins, J.Z.; Kiehart, D.P. Ion channels contribute to the regulation of cell sheet forces during Drosophila dorsal closure. Development 2014, 141, 325-334. [CrossRef]

42. Lee, H.; Nagele, R.G. Toxic and teratologic effects of verapamil on early chick embryos: Evidence for the involvement of calcium in neural tube closure. Teratology 1986, 33, 203-211. [CrossRef] [PubMed]

43. Smedley, M.J.; Stanisstreet, M. Calcium and neurulation in mammalian embryos. II. Effects of cytoskeletal inhibitors and calcium antagonists on the neural folds of rat embryos. J. Embryol. Exp. Morphol. 1986, 93, 167-178.

44. Suzuki, M.; Sato, M.; Koyama, H.; Hara, Y.; Hayashi, K.; Yasue, N.; Imamura, H.; Fujimori, T.; Nagai, T.; Campbell, R.E.; et al. Distinct intracellular $\mathrm{Ca}^{2+}$ dynamics regulate apical constriction and differentially contribute to neural tube closure. Development 2017, 144, 1307-1316. [CrossRef]

45. Sutherland, A.; Lesko, A. Pulsed actomyosin contractions in morphogenesis. F1000Research 2020, 9, 142. [CrossRef]

46. Vicente-Manzanares, M.; Ma, X.; Adelstein, R.S.; Horwitz, A.R. Non-muscle myosin II takes centre stage in cell adhesion and migration. Nat. Rev. Mol. Cell Biol. 2009, 10, 778-790. [CrossRef] [PubMed]

47. Vasquez, C.G.; Heissler, S.M.; Billington, N.; Sellers, J.R.; Martin, A.C. Drosophila non-muscle myosin II motor activity determines the rate of tissue folding. eLife 2016, 5, e20828. [CrossRef] [PubMed]

48. Verdier, V.; Chen, G.-C.; Settleman, J. Rho-kinase regulates tissue morphogenesis via non-muscle myosin and LIM-kinase during Drosophila development. BMC Dev. Biol. 2006, 6, 38. [CrossRef] [PubMed]

49. Hartshorne, D.J.; Ito, M.; Erdo“di, F. Myosin light chain phosphatase: Subunit composition, interactions and regulation. J. Muscle Res. Cell Motil. 1998, 19, 325. [CrossRef] [PubMed]

50. Totsukawa, G.; Yamakita, Y.; Yamashiro, S.; Hartshorne, D.J.; Sasaki, Y.; Matsumura, F. Distinct Roles of Rock (Rho-Kinase) and Mlck in Spatial Regulation of Mlc Phosphorylation for Assembly of Stress Fibers and Focal Adhesions in 3t3 Fibroblasts. J. Cell Biol. 2000, 150, 797-806. [CrossRef] [PubMed]

51. Kiehart, D.P.; Galbraith, C.G.; Edwards, K.A.; Rickoll, W.L.; Montague, R.A. Multiple Forces Contribute to Cell Sheet Morphogenesis for Dorsal Closure in Drosophila. J. Cell Biol. 2000, 149, 471-490. [CrossRef]

52. Martin, A.C.; Goldstein, B. Apical constriction: Themes and variations on a cellular mechanism driving morphogenesis. Development 2014, 141, 1987-1998. [CrossRef]

53. Kong, D.; Lv, Z.; Haring, M.; Lin, B.; Wolf, F.; Grosshans, J. In vivo optochemical control of cell contractility at single-cell resolution. EMBO Rep. 2019, 20, e47755. [CrossRef] [PubMed] 
54. Newell-Litwa, K.A.; Horwitz, R.; Lamers, M.L. Non-muscle myosin II in disease: Mechanisms and therapeutic opportunities. Dis. Models Mech. 2015, 8, 1495-1515. [CrossRef] [PubMed]

55. Homem, C.C.F.; Peifer, M. Diaphanous regulates myosin and adherens junctions to control cell contractility and protrusive behavior during morphogenesis. Development 2008, 135, 1005-1018. [CrossRef]

56. Chen, Y.; Ju, L.; Rushdi, M.; Ge, C.; Zhu, C. Receptor-mediated cell mechanosensing. Mol. Biol. Cell 2017, 28, 3134-3155. [CrossRef]

57. Martino, F.; Perestrelo, A.R.; Vinarský, V.; Pagliari, S.; Forte, G. Cellular Mechanotransduction: From Tension to Function. Front. Physiol. 2018, 9, 824. [CrossRef] [PubMed]

58. Martinac, B.; Kloda, A. Evolutionary origins of mechanosensitive ion channels. Prog. Biophys. Mol. Biol. 2003, 82, 11-24. [CrossRef]

59. Sharif-Naeini, R. Chapter Three-Contribution of Mechanosensitive Ion Channels to Somatosensation. In Progress in Molecular Biology and Translational Science; Price, T.J., Dussor, G., Eds.; Molecular and Cell Biology of Pain; Academic Press: Waltham, MA, USA, 2015; Volume 131, pp. 53-71.

60. Christensen, A.P.; Corey, D.P. TRP channels in mechanosensation: Direct or indirect activation? Nat. Rev. Neurosci. 2007, 8, 510-521. [CrossRef]

61. Fang, X.-Z.; Zhou, T.; Xu, J.-Q.; Wang, Y.-X.; Sun, M.-M.; He, Y.-J.; Pan, S.-W.; Xiong, W.; Peng, Z.-K.; Gao, X.-H.; et al. Structure, kinetic properties and biological function of mechanosensitive Piezo channels. Cell Biosci. 2021, 11, 13. [CrossRef]

62. Gottlieb, P.A.; Sachs, F. Piezo1. Channels 2012, 6, 214-219. [CrossRef]

63. Saotome, K.; Murthy, S.E.; Kefauver, J.M.; Whitwam, T.; Patapoutian, A.; Ward, A.B. Structure of the Mechanically Activated Ion Channel Piezo1. Nature 2018, 554, 481-486. [CrossRef]

64. Syeda, R.; Xu, J.; Dubin, A.E.; Coste, B.; Mathur, J.; Huynh, T.; Matzen, J.; Lao, J.; Tully, D.C.; Engels, I.H.; et al. Chemical activation of the mechanotransduction channel Piezo1. eLife 2015, 4, e07369. [CrossRef] [PubMed]

65. Gnanasambandam, R.; Bae, C.; Gottlieb, P.A.; Sachs, F. Ionic Selectivity and Permeation Properties of Human PIEZO1 Channels. PLoS ONE 2015, 10, e0125503. [CrossRef] [PubMed]

66. Gnanasambandam, R.; Ghatak, C.; Yasmann, A.; Nishizawa, K.; Sachs, F.; Ladokhin, A.S.; Sukharev, S.I.; Suchyna, T.M. GsMTx4: Mechanism of Inhibiting Mechanosensitive Ion Channels. Biophys. J. 2017, 112, 31-45. [CrossRef]

67. Lacroix, J.J.; Botello-Smith, W.M.; Luo, Y. Probing the gating mechanism of the mechanosensitive channel Piezo1 with the small molecule Yoda1. Nat. Commun. 2018, 9, 2029. [CrossRef]

68. Pardo-Pastor, C.; Rubio-Moscardo, F.; Vogel-González, M.; Serra, S.A.; Afthinos, A.; Mrkonjic, S.; Destaing, O.; Abenza, J.F.; Fernández-Fernández, J.M.; Trepat, X.; et al. Piezo2 channel regulates RhoA and actin cytoskeleton to promote cell mechanobiological responses. Proc. Natl. Acad. Sci. USA 2018, 115, 1925-1930. [CrossRef]

69. Gudipaty, S.A.; Lindblom, J.; Loftus, P.D.; Redd, M.J.; Edes, K.; Davey, C.F.; Krishnegowda, V.; Rosenblatt, J. Mechanical stretch triggers rapid epithelial cell division through Piezo1. Nature 2017, 543, 118-121. [CrossRef]

70. Eisenhoffer, G.T.; Loftus, P.D.; Yoshigi, M.; Otsuna, H.; Chien, C.-B.; Morcos, P.A.; Rosenblatt, J. Crowding induces live cell extrusion to maintain homeostatic cell numbers in epithelia. Nature 2012, 484, 546-549. [CrossRef]

71. Stewart, T.A.; Davis, F.M. Formation and Function of Mammalian Epithelia: Roles for Mechanosensitive PIEZO1 Ion Channels. Front. Cell Dev. Biol. 2019, 7, 260. [CrossRef] [PubMed]

72. Ranade, S.S.; Qiu, Z.; Woo, S.-H.; Hur, S.S.; Murthy, S.E.; Cahalan, S.M.; Xu, J.; Mathur, J.; Bandell, M.; Coste, B.; et al. Piezo1, a mechanically activated ion channel, is required for vascular development in mice. Proc. Natl. Acad. Sci. USA 2014, 111, 10347-10352. [CrossRef]

73. Alcaino, C.; Knutson, K.R.; Treichel, A.J.; Yildiz, G.; Strege, P.R.; Linden, D.R.; Li, J.H.; Leiter, A.B.; Szurszewski, J.H.; Farrugia, G.; et al. A population of gut epithelial enterochromaffin cells is mechanosensitive and requires Piezo2 to convert force into serotonin release. Proc. Natl. Acad. Sci. USA 2018, 115, E7632-E7641. [CrossRef] [PubMed]

74. Hu, Y.; Wang, Z.; Liu, T.; Zhang, W. Piezo-like Gene Regulates Locomotion in Drosophila Larvae. Cell Rep. 2019, 26, 1369-1377.e4. [CrossRef]

75. He, L.; Si, G.; Huang, J.; Samuel, A.D.T.; Perrimon, N. Mechanical regulation of stem-cell differentiation by the stretch-activated Piezo channel. Nature 2018, 555, 103-106. [CrossRef]

76. Beyder, A. Gut development on a full stomach. Nat. Rev. Gastroenterol. Hepatol. 2018, 15, 394-395. [CrossRef]

77. Marcovich, I.; Holt, J.R. Evolution and function of Tmc genes in mammalian hearing. Curr. Opin. Physiol. 2020, 18, 11-19. [CrossRef]

78. Kawashima, Y.; Kurima, K.; Pan, B.; Griffith, A.J.; Holt, J.R. Transmembrane channel-like (TMC) genes are required for auditory and vestibular mechanosensation. Pflug. Arch. 2015, 467, 85-94. [CrossRef] [PubMed]

79. Keresztes, G.; Mutai, H.; Heller, S. TMC and EVER genes belong to a larger novel family, the TMC gene family encoding transmembrane proteins. BMC Genom. 2003, 4, 24. [CrossRef] [PubMed]

80. Sookoian, S.; Flichman, D.; Garaycoechea, M.E.; Gazzi, C.; Martino, J.S.; Castaño, G.O.; Pirola, C.J. Lack of evidence supporting a role of TMC4 -rs641738 missense variant-MBOAT7-Intergenic downstream variant-In the Susceptibility to Nonalcoholic Fatty Liver Disease. Sci. Rep. 2018, 8, 5097. [CrossRef] [PubMed]

81. Lazarczyk, M.; Pons, C.; Mendoza, J.-A.; Cassonnet, P.; Jacob, Y.; Favre, M. Regulation of cellular zinc balance as a potential mechanism of EVER-mediated protection against pathogenesis by cutaneous oncogenic human papillomaviruses. J. Exp. Med. 2008, 205, 35-42. [CrossRef] 
82. Pan, B.; Géléoc, G.S.; Asai, Y.; Horwitz, G.C.; Kurima, K.; Ishikawa, K.; Kawashima, Y.; Griffith, A.J.; Holt, J.R. TMC1 and TMC2 are components of the mechanotransduction channel in hair cells of the mammalian inner ear. Neuron 2013, 79, 504-515. [CrossRef]

83. Chou, S.-W.; Chen, Z.; Zhu, S.; Davis, R.W.; Hu, J.; Liu, L.; Fernando, C.A.; Kindig, K.; Brown, W.C.; Stepanyan, R.; et al. A molecular basis for water motion detection by the mechanosensory lateral line of zebrafish. Nat. Commun. 2017, 8, 2234. [CrossRef]

84. Hudspeth, A.J. How the ear's works work. Nature 1989, 341, 397-404. [CrossRef] [PubMed]

85. Maeda, R.; Kindt, K.S.; Mo, W.; Morgan, C.P.; Erickson, T.; Zhao, H.; Clemens-Grisham, R.; Barr-Gillespie, P.G.; Nicolson, T. Tip-link protein protocadherin 15 interacts with transmembrane channel-like proteins TMC1 and TMC2. Proc. Natl. Acad. Sci. USA 2014, 111, 12907-12912. [CrossRef] [PubMed]

86. Beurg, M.; Xiong, W.; Zhao, B.; Müller, U.; Fettiplace, R. Subunit determination of the conductance of hair-cell mechanotransducer channels. Proc. Natl. Acad. Sci. USA 2015, 112, 1589-1594. [CrossRef]

87. Tang, Y.-Q.; Lee, S.A.; Rahman, M.; Vanapalli, S.A.; Lu, H.; Schafer, W.R. Ankyrin Is An Intracellular Tether for TMC Mechanotransduction Channels. Neuron 2020, 107, 112-125.e10. [CrossRef]

88. Corey, D.P.; Akyuz, N.; Holt, J.R. Function and Dysfunction of TMC Channels in Inner Ear Hair Cells. Cold Spring Harb. Perspect. Med. 2019, 9, a033506. [CrossRef] [PubMed]

89. Kawashima, Y.; Géléoc, G.S.G.; Kurima, K.; Labay, V.; Lelli, A.; Asai, Y.; Makishima, T.; Wu, D.K.; Della Santina, C.C.; Holt, J.R.; et al. Mechanotransduction in mouse inner ear hair cells requires transmembrane channel-like genes. J. Clin. Investig. 2011, 121, 4796-4809. [CrossRef]

90. Nakanishi, H.; Kurima, K.; Pan, B.; Wangemann, P.; Fitzgerald, T.S.; Géléoc, G.S.; Holt, J.R.; Griffith, A.J. Tmc2 expression partially restores auditory function in a mouse model of DFNB7/B11 deafness caused by loss of Tmc1 function. Sci. Rep. 2018, 8, 12125. [CrossRef] [PubMed]

91. Guo, Y.; Wang, Y.; Zhang, W.; Meltzer, S.; Zanini, D.; Yu, Y.; Li, J.; Cheng, T.; Guo, Z.; Wang, Q.; et al. Transmembrane channel-like $(t m c)$ gene regulates Drosophila larval locomotion. Proc. Natl. Acad. Sci. USA 2016, 113, 7243-7248. [CrossRef]

92. Richa, P. Role of Mechanosensitive Ion Channels in Coordinated Epithelial Cell Dynamics in Drosophila. Ph.D. Thesis, GeorgAugust-Universität Göttingen, Göttingen, Germany, 2019.

93. Pedersen, S.F.; Owsianik, G.; Nilius, B. TRP channels: An overview. Cell Calcium 2005, 38, 233-252. [CrossRef]

94. Jin, P.; Bulkley, D.; Guo, Y.; Zhang, W.; Guo, Z.; Huynh, W.; Wu, S.; Meltzer, S.; Cheng, T.; Jan, L. Y.; et al. Cryo-EM Structure of the Mechanotransduction Channel NOMPC. Nature 2017, 547, 118-122. [CrossRef]

95. Wang, Y.; Guo, Y.; Li, G.; Liu, C.; Wang, L.; Zhang, A.; Yan, Z.; Song, C. The push-to-open mechanism of the tethered mechanosensitive ion channel NompC. eLife 2021, 10, e58388. [CrossRef]

96. Ferrandiz-Huertas, C.; Mathivanan, S.; Wolf, C.; Devesa, I.; Ferrer-Montiel, A. Trafficking of ThermoTRP Channels. Membranes 2014, 4, 525-564. [CrossRef] [PubMed]

97. Lehnert, B.P.; Baker, A.E.; Gaudry, Q.; Chiang, A.-S.; Wilson, R.I. Distinct Roles of TRP Channels in Auditory Transduction and Amplification in Drosophila. Neuron 2013, 77, 115-128. [CrossRef]

98. Yan, Z.; Zhang, W.; He, Y.; Gorczyca, D.; Xiang, Y.; Cheng, L.E.; Meltzer, S.; Jan, L.Y.; Jan, Y.N. Drosophila NOMPC is a mechanotransduction channel subunit for gentle-touch sensation. Nature 2013, 493, 221-225. [CrossRef] [PubMed]

99. Hunter, G. The Role of Mechanically Gated Ion Channels in Dorsal Closure during Drosophila Morphogenesis. Ph.D. Thesis, Duke University, Durham, NC, USA, 2012.

100. Miledi, R. A calcium-dependent transient outward current in Xenopus laevis oocytes. Proc. R. Soc. Lond. Ser. B Biol. Sci. 1982, 215, 491-497. [CrossRef]

101. Barish, M.E. A transient calcium-dependent chloride current in the immature Xenopus oocyte. J. Physiol. 1983, 342, 309-325. [CrossRef]

102. Schroeder, B.C.; Cheng, T.; Jan, Y.N.; Jan, L.Y. Expression cloning of TMEM16A as a calcium-activated chloride channel subunit. Cell 2008, 134, 1019-1029. [CrossRef]

103. Yang, Y.D.; Cho, H.; Koo, J.Y.; Tak, M.H.; Cho, Y.; Shim, W.-S.; Park, S.P.; Lee, J.; Lee, B.; Kim, B.-M.; et al. TMEM16A confers receptor-activated calcium-dependent chloride conductance. Nature 2008, 455, 1210-1215. [CrossRef]

104. Caputo, A.; Caci, E.; Ferrera, L.; Pedemonte, N.; Barsanti, C.; Sondo, E.; Pfeffer, U.; Ravazzolo, R.; Zegarra-Moran, O.; Galietta, L.J.V. TMEM16A, A Membrane Protein Associated with Calcium-Dependent Chloride Channel Activity. Science 2008, 322, 590-594. [CrossRef]

105. Kalienkova, V.; Clerico Mosina, V.; Paulino, C. The Groovy TMEM16 Family: Molecular Mechanisms of Lipid Scrambling and Ion Conduction. J. Mol. Biol. 2021, 433, 166941. [CrossRef] [PubMed]

106. Dang, S.; Feng, S.; Tien, J.; Peters, C.J.; Bulkley, D.; Lolicato, M.; Zhao, J.; Zuberbühler, K.; Ye, W.; Qi, L.; et al. Cryo-EM structures of the TMEM16A calcium-activated chloride channel. Nature 2017, 552, 426-429. [CrossRef] [PubMed]

107. Medrano-Soto, A.; Moreno-Hagelsieb, G.; McLaughlin, D.; Ye, Z.S.; Hendargo, K.J.; Saier, M.H. Bioinformatic characterization of the Anoctamin Superfamily of $\mathrm{Ca}^{2+}$-activated ion channels and lipid scramblases. PLoS ONE 2018, 13, e0192851. [CrossRef]

108. Dutta, A.K.; Woo, K.; Khimji, A.; Kresge, C.; Feranchak, A.P. Mechanosensitive Cl- secretion in biliary epithelium mediated through TMEM16A. Am. J. Physiol. Gastrointest. Liver Physiol. 2013, 304, G87-G98. [CrossRef] [PubMed] 
109. Chintapalli, V.R.; Wang, J.; Dow, J.A.T. Using FlyAtlas to identify better Drosophila melanogaster models of human disease. Nat. Genet. 2007, 39, 715-720. [CrossRef] [PubMed]

110. Lemaitre, B.; Hoffmann, J. The Host Defense of Drosophila melanogaster. Annu. Rev. Immunol. 2007, 25, 697-743. [CrossRef]

111. Wong, X.M.; Younger, S.; Peters, C.J.; Jan, Y.N.; Jan, L.Y. Subdued, a TMEM16 family $\mathrm{Ca}^{2+}$-activated $\mathrm{Cl}^{-}$channel in Drosophila melanogaster with an unexpected role in host defense. eLife 2013, 2, e00862. [CrossRef]

112. He, M.; Ye, W.; Wang, W.-J.; Sison, E.S.; Jan, Y.N.; Jan, L.Y. Cytoplasmic Cl- couples membrane remodeling to epithelial morphogenesis. Proc. Natl. Acad. Sci. USA 2017, 114, E11161-E11169. [CrossRef]

113. Narayanan, V.; Schappell, L.E.; Mayer, C.R.; Duke, A.A.; Armiger, T.J.; Arsenovic, P.T.; Mohan, A.; Dahl, K.N.; Gleghorn, J.P.; Conway, D.E. Osmotic Gradients in Epithelial Acini Increase Mechanical Tension across E-cadherin, Drive Morphogenesis, and Maintain Homeostasis. Curr. Biol. 2020, 30, 624-633.e4. [CrossRef]

114. George, L.F.; Pradhan, S.J.; Mitchell, D.; Josey, M.; Casey, J.; Belus, M.T.; Fedder, K.N.; Dahal, G.R.; Bates, E.A. Ion Channel Contributions to Wing Development in Drosophila melanogaster. G3 Genes Genomes Genet. 2019, 9, 999-1008. [CrossRef]

115. Beyder, A.; Rae, J.L.; Bernard, C.; Strege, P.R.; Sachs, F.; Farrugia, G. Mechanosensitivity of Nav1.5, a voltage-sensitive sodium channel. J. Physiol. 2010, 588, 4969-4985. [CrossRef]

116. Canessa, C.M.; Merillat, A.M.; Rossier, B.C. Membrane topology of the epithelial sodium channel in intact cells. Am. J. Physiol.-Cell Physiol. 1994, 267, C1682-C1690. [CrossRef]

117. Duc, C.; Farman, N.; Canessa, C.M.; Bonvalet, J.P.; Rossier, B.C. Cell-specific expression of epithelial sodium channel alpha, beta, and gamma subunits in aldosterone-responsive epithelia from the rat: Localization by in situ hybridization and immunocytochemistry. J. Cell Biol. 1994, 127, 1907-1921. [CrossRef] [PubMed]

118. Hanukoglu, I.; Boggula, V.R.; Vaknine, H.; Sharma, S.; Kleyman, T.; Hanukoglu, A. Expression of epithelial sodium channel $(\mathrm{ENaC})$ and CFTR in the human epidermis and epidermal appendages. Histochem. Cell Biol. 2017, 147, 733-748. [CrossRef] [PubMed]

119. Hanukoglu, I.; Hanukoglu, A. Epithelial sodium channel (ENaC) family: Phylogeny, structure-function, tissue distribution, and associated inherited diseases. Gene 2016, 579, 95-132. [CrossRef] [PubMed]

120. Sharma, S.; Kumaran, G.K.; Hanukoglu, I. High-resolution imaging of the actin cytoskeleton and epithelial sodium channel, CFTR, and aquaporin-9 localization in the vas deferens. Mol. Reprod. Dev. 2020, 87, 305-319. [CrossRef]

121. Wang, S.; Meng, F.; Mohan, S.; Champaneri, B.; Gu, Y. Functional ENaC Channels Expressed in Endothelial Cells: A New Candidate for Mediating Shear Force. Microcirculation 2009, 16, 276-287. [CrossRef]

122. Knoepp, F.; Ashley, Z.; Barth, D.; Baldin, J.-P.; Jennings, M.; Kazantseva, M.; Saw, E.L.; Katare, R.; de la Rosa, D.A.; Weissmann, $\mathrm{N}$; ; et al. Shear force sensing of epithelial $\mathrm{Na}+$ channel $(\mathrm{ENaC})$ relies on $\mathrm{N}$-glycosylated asparagines in the palm and knuckle domains of $\alpha \mathrm{ENaC}$. Proc. Natl. Acad. Sci. USA 2020, 117, 717-726. [CrossRef]

123. Morachevskaya, E.A.; Sudarikova, A.V. Actin dynamics as critical ion channel regulator: ENaC and Piezo in focus. Am. J. Physiol.-Cell Physiol. 2021, 320, C696-C702. [CrossRef]

124. Ilatovskaya, D.V.; Pavlov, T.S.; Levchenko, V.; Negulyaev, Y.A.; Staruschenko, A. Cortical actin binding protein cortactin mediates ENaC activity via Arp2/3 complex. FASEB J. 2011, 25, 2688-2699. [CrossRef]

125. Mazzochi, C.; Bubien, J.K.; Smith, P.R.; Benos, D.J. The Carboxyl Terminus of the $\alpha$-Subunit of the Amiloride-sensitive Epithelial Sodium Channel Binds to F-actin. J. Biol. Chem. 2006, 281, 6528-6538. [CrossRef]

126. Althaus, M.; Bogdan, R.; Clauss, W.G.; Fronius, M. Mechano-sensitivity of epithelial sodium channels (ENaCs): Laminar shear stress increases ion channel open probability. FASEB J. 2007, 21, 2389-2399. [CrossRef]

127. Hall, D.H.; Gu, G.; García-Añoveros, J.; Gong, L.; Chalfie, M.; Driscoll, M. Neuropathology of Degenerative Cell Death in Caenorhabditis elegans. J. Neurosci. 1997, 17, 1033-1045. [CrossRef]

128. Geffeney, S.L.; Goodman, M.B. How we feel: Ion channel partnerships that detect mechanical inputs and give rise to touch and pain perception. Neuron 2012, 74, 609-619. [CrossRef]

129. Adams, C.M.; Anderson, M.G.; Motto, D.G.; Price, M.P.; Johnson, W.A.; Welsh, M.J. Ripped Pocket and Pickpocket, Novel Drosophila DEG/ENaC Subunits Expressed in Early Development and in Mechanosensory Neurons. J. Cell Biol. 1998, 140, 143-152. [CrossRef] [PubMed]

130. Emmons-Bell, M.; Hariharan, I.K. Membrane potential regulates Hedgehog signaling in the Drosophila wing disc. EMBO Rep. 2021, 22, e51861. [CrossRef] [PubMed]

131. Enyedi, P.; Czirják, G. Molecular Background of Leak K+ Currents: Two-Pore Domain Potassium Channels. Physiol. Rev. 2010, 90, 559-605. [CrossRef]

132. Ketchum, K.A.; Joiner, W.J.; Sellers, A.J.; Kaczmarek, L.K.; Goldstein, S.A.N. A new family of outwardly rectifying potassium channel proteins with two pore domains in tandem. Nature 1995, 376, 690-695. [CrossRef] [PubMed]

133. Honoré, E. The neuronal background K 2P channels: Focus on TREK1. Nat. Rev. Neurosci. 2007, 8, 251-261. [CrossRef] [PubMed]

134. Fink, M.; Duprat, F.; Lesage, F.; Reyes, R.; Romey, G.; Heurteaux, C.; Lazdunski, M. Cloning, functional expression and brain localization of a novel unconventional outward rectifier $\mathrm{K}+$ channel. EMBO J. 1996, 15, 6854-6862. [CrossRef]

135. Fink, M.; Lesage, F.; Duprat, F.; Heurteaux, C.; Reyes, R.; Fosset, M.; Lazdunski, M. A neuronal two P domain K+ channel stimulated by arachidonic acid and polyunsaturated fatty acids. EMBO J. 1998, 17, 3297-3308. [CrossRef] 
136. Lesage, F.; Terrenoire, C.; Romey, G.; Lazdunski, M. Human TREK2, a 2P Domain Mechano-sensitive K+ Channel with Multiple Regulations by Polyunsaturated Fatty Acids, Lysophospholipids, and Gs, Gi, and Gq Protein-coupled Receptors. J. Biol. Chem. 2000, 275, 28398-28405. [CrossRef] [PubMed]

137. Patel, A.J.; Honoré, E.; Maingret, F.; Lesage, F.; Fink, M.; Duprat, F.; Lazdunski, M. A mammalian two pore domain mechano-gated S-like K+ channel. EMBO J. 1998, 17, 4283-4290. [CrossRef] [PubMed]

138. Cross-talk between the mechano-gated K2P channel TREK-1 and the actin cytoskeleton. EMBO Rep. 2005, 6, 642-648. [CrossRef] [PubMed]

139. Roan, E.; Waters, C.M.; Teng, B.; Ghosh, M.; Schwingshackl, A. The 2-Pore Domain Potassium Channel TREK-1 Regulates Stretch-Induced Detachment of Alveolar Epithelial Cells. PLoS ONE 2014, 9, e89429. [CrossRef]

140. Patel, S.K.; Jackson, L.; Warren, A.Y.; Arya, P.; Shaw, R.W.; Khan, R.N. A role for two-pore potassium (K2P) channels in endometrial epithelial function. J. Cell. Mol. Med. 2013, 17, 134-146. [CrossRef]

141. Abraham, D.M.; Lee, T.E.; Watson, L.J.; Mao, L.; Chandok, G.; Wang, H.-G.; Frangakis, S.; Pitt, G.S.; Shah, S.H.; Wolf, M.J.; et al. The two-pore domain potassium channel TREK-1 mediates cardiac fibrosis and diastolic dysfunction. J. Clin. Investig. 2018, 128, 4843-4855. [CrossRef] [PubMed]

142. Zhang, X.; Zheng, Y.; Ren, Q.; Zhou, H. The involvement of potassium channel ORK1 in short-term memory and sleep in Drosophila. Medicine 2017, 96, e7299. [CrossRef]

143. Lalevée, N.; Monier, B.; Sénatore, S.; Perrin, L.; Sémériva, M. Control of Cardiac Rhythm by ORK1, a Drosophila Two-Pore Domain Potassium Channel. Curr. Biol. 2006, 16, 1502-1508. [CrossRef]

144. Ben-Abu, Y.; Zhou, Y.; Zilberberg, N.; Yifrach, O. Inverse coupling in leak and voltage-activated K+ channel gates underlies distinct roles in electrical signaling. Nat. Struct. Mol. Biol. 2009, 16, 71-79. [CrossRef]

145. Ben Soussia, I.; El Mouridi, S.; Kang, D.; Leclercq-Blondel, A.; Khoubza, L.; Tardy, P.; Zariohi, N.; Gendrel, M.; Lesage, F.; Kim, E.-J.; et al. Mutation of a single residue promotes gating of vertebrate and invertebrate two-pore domain potassium channels. Nat. Commun. 2019, 10, 787. [CrossRef]

146. Häring, M.; Großhans, J.; Wolf, F.; Eule, S. Automated Segmentation of Epithelial Tissue Using Cycle-Consistent Generative Adversarial Networks. bioRxiv 2018, 311373. [CrossRef]

147. Notbohm, J.; Napiwocki, B.N.; de Lange, W.J.; Stempien, A.; Saraswathibhatla, A.; Craven, R.J.; Salick, M.R.; Ralphe, J.C.; Crone, W.C. Two-Dimensional Culture Systems to Enable Mechanics-Based Assays for Stem Cell-Derived Cardiomyocytes. Exp. Mech. 2019, 59, 1235-1248. [CrossRef]

148. Hu, Q.; Wolfner, M.F. The Drosophila Trpm channel mediates calcium influx during egg activation. Proc. Natl. Acad. Sci. USA 2019, 116, 18994-19000. [CrossRef] [PubMed]

149. Antunes, M.; Pereira, T.; Cordeiro, J.V.; Almeida, L.; Jacinto, A. Coordinated waves of actomyosin flow and apical cell constriction immediately after wounding. J. Cell Biol. 2013, 202, 365-379. [CrossRef]

150. Zhang, M.; Li, X.; Zheng, H.; Wen, X.; Chen, S.; Ye, J.; Tang, S.; Yao, F.; Li, Y.; Yan, Z. Brv1 Is Required for Drosophila Larvae to Sense Gentle Touch. Cell Rep. 2018, 23, 23-31. [CrossRef] [PubMed]

151. Murthy, S.E.; Dubin, A.E.; Whitwam, T.; Jojoa-Cruz, S.; Cahalan, S.M.; Mousavi, S.A.R.; Ward, A.B.; Patapoutian, A. OSCA/TMEM63 are an evolutionarily conserved family of mechanically activated ion channels. eLife 2018, 7, e41844. [CrossRef] [PubMed] 